\title{
Quantifying Surface Urban Heat Island Formation in the World Heritage Tropical Mountain City of Sri Lanka
}

\author{
Manjula Ranagalage ${ }^{1,2, *(\mathbb{D})}$, DMSLB Dissanayake ${ }^{1,2, *(1)}$, Yuji Murayama ${ }^{3}(\mathbb{C})$, Xinmin Zhang ${ }^{1, *}$, \\ Ronald C. Estoque ${ }^{4}$, ENC Perera ${ }^{5}$ and Takehiro Morimoto ${ }^{3}$ \\ 1 Graduate School of Life and Environmental Sciences, University of Tsukuba, 1-1-1 Tennodai, Tsukuba, \\ Ibaraki 305-8572, Japan \\ 2 Department of Environmental Management, Faculty of Social Sciences and Humanities, \\ Rajarata University of Sri Lanka, Mihintale 50300, Sri Lanka \\ 3 Faculty of Life and Environmental Sciences, University of Tsukuba, 1-1-1, Tennodai, Tsukuba, \\ Ibaraki 305-8572, Japan; mura@geoenv.tsukuba.ac.jp (Y.M.); tmrmt@geoenv.tsukuba.ac.jp (T.M.) \\ 4 Center for Social and Environmental Systems Research, National Institute for Environmental Studies, \\ 16-2 Onogawa, Tsukuba, Ibaraki 305-8506, Japan; rons2k@yahoo.co.uk \\ 5 Institute of Human Resource Advancement (IHRA), University of Colombo, Colombo 00700, Sri Lanka; \\ chinssu@gmail.com \\ * Correspondence: manjularanagalage@gmail.com (M.R.); dissanayakedmslb@gmail.com (D.D.); \\ xinmin@geoenv.tsukuba.ac.jp (X.Z.); Tel.: +81-029-853-4211 (M.R. \& D.D. \& X.Z.)
}

Received: 22 June 2018; Accepted: 20 August 2018; Published: 22 August 2018

\begin{abstract}
Presently, the urban heat island (UHI) phenomenon, and its adverse impacts, are becoming major research foci in various interrelated fields due to rapid changes in urban ecological environments. Various cities have been investigated in previous studies, and most of the findings have facilitated the introduction of proper mitigation measures to overcome the negative impact of UHI. At present, most of the mountain cities of the world have undergone rapid urban development, and this has resulted in the increasing surface UHI (SUHI) phenomenon. Hence, this study focuses on quantifying SUHI in Kandy City, the world heritage tropical mountain city of Sri Lanka, using Landsat data (1996 and 2017) based on the mean land surface temperature (LST), the difference between the fraction of impervious surfaces (IS), and the fraction of green space (GS). Additionally, we examined the relationship of LST to the green space/impervious surface fraction ratio (GS/IS fraction ratio) and the magnitude of the GS/IS fraction ratio. The SUHI intensity (SUHII) was calculated based on the temperature difference between main land use/cover categories and the temperature difference between urban-rural zones. We demarcated the rural zone based on the fraction of IS recorded, $<10 \%$, along with the urban-rural gradient zone. The result shows a SUHII increase from $3.9^{\circ} \mathrm{C}$ in 1996 to $6.2{ }^{\circ} \mathrm{C}$ in 2017 along the urban-rural gradient between the urban and rural zones $(10<$ IS). These results relate to the rapid urban expansion of the study areas from 1996 to 2017. Most of the natural surfaces have changed to impervious surfaces, causing an increase of SUHI in Kandy City. The mean LST has a positive relationship with the fraction of IS and a negative relationship with the fraction of GS. Additionally, the GS/IS fraction ratio shows a rapid decline. Thus, the findings of this study can be considered as a proxy indicator for introducing proper landscape and urban planning for the World Heritage tropical mountain city of Kandy in Sri Lanka.
\end{abstract}

Keywords: land surface temperature; urban heat island; urban heat island intensity; gradient analysis; impervious surface; green surface; Kandy City; Sri Lanka 


\section{Introduction}

Urban heat island (UHI), a phenomenon of higher air and surface temperatures occurring in urban and suburban areas, has been examined in comparison with neighbouring rural areas $[1,2]$. The cities with populations of one million or more recorded mean annual temperature differences of $1-3{ }^{\circ} \mathrm{C}$ in comparison with the rural surroundings and, on a calm night, this temperature variation has been observed to rise as high as $12{ }^{\circ} \mathrm{C}$ as a result of the slow release of heat due to longwave radiation from urban surfaces [2,3]. The UHI can be observed even in smaller cities and towns, and its effects depend on the size of the city [2,4]. The UHI measure based on the land surface temperature (LST) is called surface UHI (SUHI). The SUHI is highest in the daytime when the sun is shining [2].

Urbanization provides an improvement in the socio-economic benefits of the population, but it also has an adverse impact on the environment $[5,6]$. The formation of SUHI is one of the significant negative phenomena because it is a by-product of rapid urbanization [7]. This rapid urban growth has caused a decrease in urban green areas when they are converted to impervious surfaces (roads, parking lots, buildings, and other constructions) [8]. Green spaces can control the SUHI by providing cooling effects through evapotranspiration [2]. Conversely, increasing impervious surfaces has resulted in intensifying SUHI due to the reflectance of more solar radiation [2]. Thus, the fractions of impervious surfaces and green spaces are important for the study of the formation of SUHI [7,9-11].

The urban area has undergone SUHI effects due to the rapid changes in urban landscapes [8]. There are several negative impacts associated with SUHI, such as increasing consumption of energy, influence on human health and comfort [2], and weakening of living environments [12]. Thus, it is vital to understand the SUHI formation in order to introduce proper mitigation measures. Formerly, most SUHI studies focused on various types of cities, such as tropical coastal cities [11,13,14], desert cities [9,15], and mountain cities [7]. Hence, studies regarding the SUHI formation in mountain cities are becoming important for identifying the rapid changing patterns of the thermal environment.

The mountain cities located in Asia became more developed during the 19th and 20th centuries during the colonization era $[6,16]$. The mountain cities generally record lower temperatures than their neighbouring low land areas. Thus, these cool natural environments have been beneficial to the residential population, tourists, and visitors [5]. Most mountain cities became multi-functional cities after the Second World War [6]. Presently, however, most mountain cities are undergoing rapid urban development, such as increasing built-up areas and growing populations [6]. Thus, most of the natural surfaces have been replaced by developed surfaces, resulting in several environmental issues, such as SUHI [7]. The mean LST differences between major land-use categories, such as green space (GS) and impervious surfaces (IS) of mountain cities are similar to the low land cities [7]. Mountain cities have a high potential for rapid development due to the accelerating economic growth of the country. Therefore, it is essential to assess the current status and challenges of landscape changes, and use the results for the betterment of future urban sustainability of mountain cities [6]. Hence, this study focuses on quantifying SUHI formation in the tropical mountain city of Kandy.

The observation of SUHI intensity (SUHII) is essential to identifying the SUHI phenomenon [7]. SUHII can be used to compare two or more time periods without considering the absolute LST changes $[17,18]$. The SUHII can be measured based on the LST. It can be calculated based on two methods. The first is the temperature difference between urban-rural areas $[1,7,19,20]$. This can be calculated based on the urban-rural gradient analysis. The gradient analysis can be used to identify the spatial variation of environmental variables concerning distance [21]. It has been used to demarcate the spatiotemporal variation of the LST in some previous studies $[7,8,11,22]$. The rural zone was demarcated based on the fraction of IS (the first zone recoded fraction of IS $<10 \%$ ) from the city centre [7]. The second method is based on the urban land use/cover $[7,23,24]$. It can be measured by classifying the urban land use/cover into local climate zones and, thereafter, the inter-zone comparison method can be used $[7,23,24]$. The present study adopted available methodologies related to SUHII calculation for quantifying SUHI formation in Kandy. Additionally, the GS and IS combination provides a better picture for understanding the SUHI formation. 
IS and GS have been employed to identify SUHI in different landscapes $[7,9,11,25,26]$. IS areas have been highly associated with the increase in SUHI, and high IS surfaces have recorded relatively higher temperatures than their surrounding green areas [25]. GS plays a vital role in reducing the SUHI effects, and $10 \%$ of green cover can have the result of reducing the LST by $0.86{ }^{\circ} \mathrm{C}[25,27]$. The authors hypothesize that a combination of GS and IS as a ratio could have an influence on SUHI formation. We propose the green surface/impervious surface (GS/IS) fraction ratio to understand SUHI formation in the tropical mountain city of Kandy.

Most previous SUHI studies in Sri Lanka have focused on the Colombo area, the commercial capital of the country $[8,13,28]$. However, SUHI studies are lacking in Kandy City. Kandy City was established in 14th Century AD and is one of the top tourist destinations in Sri Lanka due to its cultural diversity and scenic beauty [29]. This city is famous for the Temple of the Tooth and many other temples and archaeological monuments. Hence, it is called the cultural capital of Sri Lanka [29]. UNESCO declared it as a World Heritage City in 1988 [30]. Kandy City has undergone rapid urban development since it is the most prominent city located in the central highlands of Sri Lanka. Hence, more urban-related environmental issues are prominent in this area. Thus, the authors hypothesize that rapid urban development could influence SUHI formation in the study area. This study aims to provide a better understanding of SUHI formation in a tropical mountain city by using several variables, such as the fractions of impervious surfaces and green surfaces, and to create a green space impervious surface fraction ratio. The result of this study can be used as a proxy indicator for urban landscape planning to achieve urban sustainability.

\section{Materials and Methods}

\subsection{Study Area: Kandy City, Sri Lanka}

Kandy is referred to as the second largest city in Sri Lanka, and its population is more than 170,000 [31]. The geographic location of Kandy City extends from $7^{\circ} 12^{\prime} 9.24^{\prime \prime} \mathrm{N}$ to $7^{\circ} 23^{\prime} 1.06^{\prime \prime} \mathrm{N}$ latitude and from $80^{\circ} 32^{\prime} 41.27^{\prime \prime} \mathrm{E}$ to $80^{\circ} 43^{\prime} 32.16^{\prime \prime} \mathrm{E}$ longitude (Figure 1). Taking a geographical perspective, it is a hill and valley city in the centre of Sri Lanka, surrounded by two mountain ranges, Knuckles and Hanthana [31], and it has an average elevation of $465 \mathrm{~m}$. The study area consists of the landscape within a $20 \times 20 \mathrm{~km}$ grid from Kandy City centre $\left(400 \mathrm{~km}^{2}\right)$.

As seen from a climatological viewpoint, Kandy is located in the tropical monsoon region, characterized by heavy rainfall and relatively constant, warm temperatures and humidity. It has an extended period of heavy rainfall from May to September, which is affected by the Southwest monsoon [32]. However, the Northeast monsoon (December to February) brings less precipitation [32]. The monthly rainfall over Kandy is approximately $52-398 \mathrm{~mm}$, but might fluctuate due to seasonal variations and climate changes [31]. The dry period is from January to April, and the average ambient temperature in the daytime is in the range of $28-32{ }^{\circ} \mathrm{C}$ [31] because the weather is rough and unstable during this period.

\subsection{Satellite Data Descriptions and Pre-Processing}

The Landsat images were captured in the dry season, specifically on 8 March 1996 (Landsat 5 TM), 5 April 2006 (Landsat 5 TM) and 18 March 2017 (Landsat 8 OLI/TIRS) (Table 1a). Kandy is located on path 141 and row 55 . Less than $10 \%$ of cloud-free images were selected for this analysis. Table $1 \mathrm{~b}$ shows the weather condition data of the study area pertaining to the image acquisition dates provided by the Department of Meteorology, Sri Lanka. Generally, there is no significant variation in weather conditions during this period (Table $1 b$ ). 


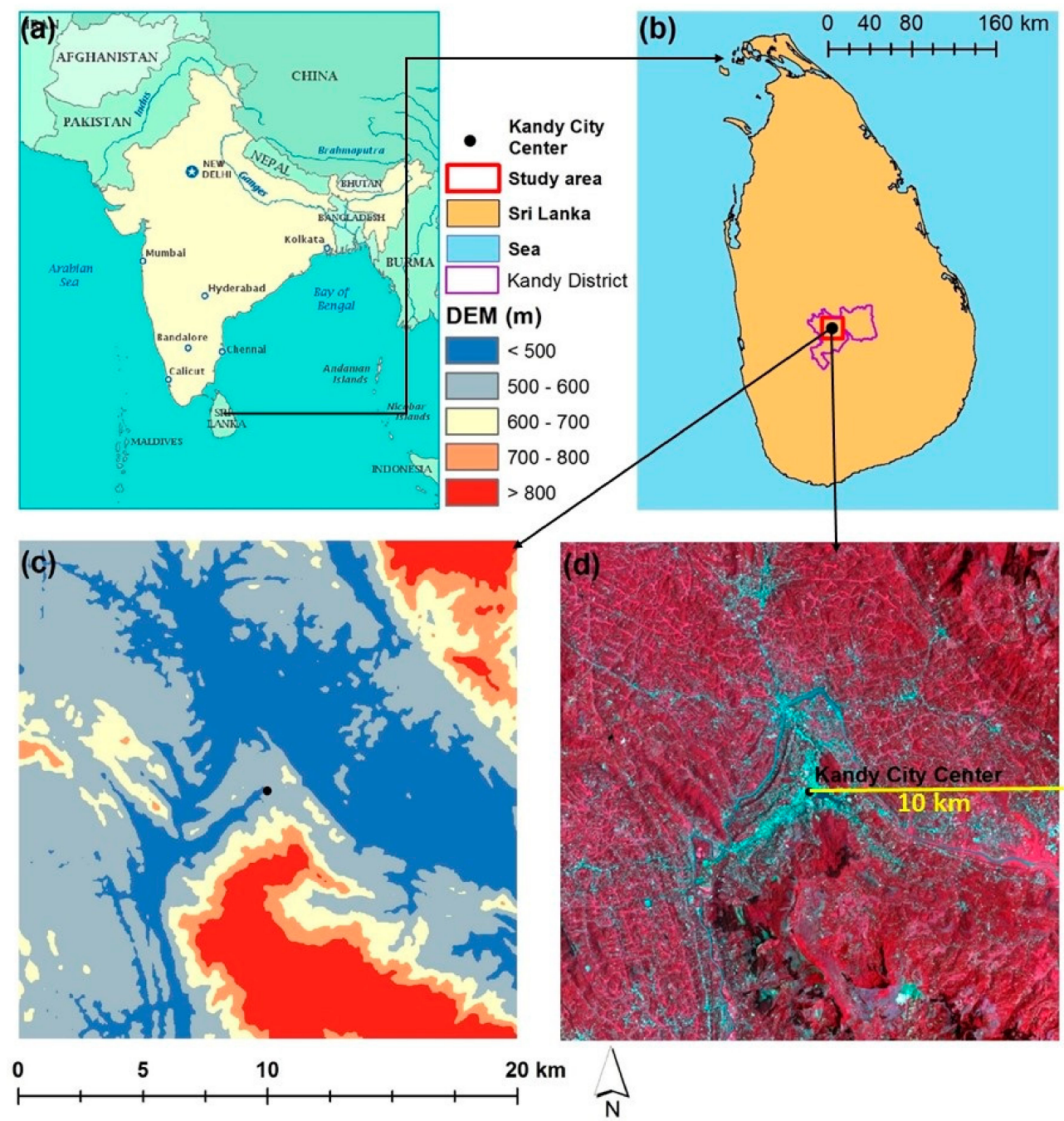

Figure 1. Location of the study area: (a) map of South Asia (www.yourchildlearns.com); (b) Location of Kandy City; (c) digital elevation maps of Kandy City (https:/ / earthexplorer.usgs.gov/); and (d) Landsat 8 image displayed in a false colour composite (bands 5, 4, and 3) (18 March 2017) (https: / / earthexplorer.usgs.gov/).

Table 1. Descriptions of the Landsat images and weather conditions for the image acquisition dates.

\begin{tabular}{|c|c|c|c|c|}
\hline \multicolumn{5}{|c|}{ (a) Description of Landsat images } \\
\hline Sensor & Scene ID & Acquisition Date & Time (GMT) & Season \\
\hline Landsat $5 \mathrm{TM}$ & LT51410551996068BKT00 & 8 March 1996 & 04:00:49 & Dry \\
\hline Landsat $5 \mathrm{TM}$ & LT51410552006095BКT00 & 5 April 2006 & $04: 45: 26$ & Dry \\
\hline Landsat 8 OLI/TIRS & LC81410552017077LGN00 & 18 March 2017 & 04:53:36 & Dry \\
\hline \multicolumn{5}{|c|}{ (b) The weather conditions of the study area (Data source: Department of Meteorology, Sri Lanka) } \\
\hline Weather parameters & Acquisition Date & 8 March 1996 & 5 April 2006 & 8 March 2017 \\
\hline \multirow{3}{*}{ Air Temperature $\left({ }^{\circ} \mathrm{C}\right)$} & Maximum & 32 & 31.5 & 30.8 \\
\hline & Minimum & 19.4 & 20.4 & 16.1 \\
\hline & Mean & 25.7 & 25.95 & 23.45 \\
\hline \multirow{3}{*}{ Relative Humidity (\%) } & Maximum & 83 & 96 & 86 \\
\hline & Minimum & 52 & 67 & 61 \\
\hline & Mean & 67.5 & 81.5 & 73.5 \\
\hline Rainfall (mm) & Rainfall & 0 & 3.6 & 0 \\
\hline
\end{tabular}


The selected satellite images were mapped using WGS84/UTM $44 \mathrm{~N}$ projection. The projected images were subjected to radiometric calibration and atmospheric correction using the Terrset software developed by Clark University, USA. During this process, (i) the digital numbers (DN) of all multispectral bands were converted to surface reflectance values based on the dark object subtraction method; and (ii) the DN values of thermal bands were converted to at-satellite brightness temperatures in degrees Kelvin [11], all performed automatically by the TerrSet software $[7,11,25]$.

\subsection{Land Use/Cover Mapping}

We used four types of classification methods (support vector machine, K-nearest neighbour, random forest, and neural networks); among them, both overall accuracy and kappa statistics were higher when using the support vector machine method. Hence, this method was selected [33-36]. The three images used were classified into six categories: impervious surface (IS); forest; grassland; bareland; cropland, and water. The authors used (i) IS; (ii) green space 1 (forest) and (iii) green space 2 (grassland and cropland) [7] for the current study.

\subsection{LST Retrieval}

The LST was extracted by using the pre-processed thermal bands produced in Section 2.2, containing at-satellite brightness temperatures (expressed in degrees Kelvin). The at-satellite brightness temperatures were scaled by using land surface emissivity $[7,11,22,25]$. The emissivity was calculated by using Equation (1) [37]:

$$
\varepsilon=m P_{v}+n
$$

where, $m=\left(\varepsilon_{\mathrm{V}}-\varepsilon_{\mathrm{S}}\right)-\left(1-\varepsilon_{\mathrm{S}}\right) \mathrm{F} \varepsilon_{\mathrm{V}}$ and $n=\varepsilon_{\mathrm{S}}+\left(1-\varepsilon_{\mathrm{S}}\right) \mathrm{F} \varepsilon_{\mathrm{V}}$, where $\varepsilon_{\mathrm{S}}$ and $\varepsilon_{\mathrm{V}}$ are the soil emissivity and vegetation emissivity, respectively. The result by Sobrino et al. [37] was used for $m=0.004$ and $n=0.986$. The proportion of vegetation $\left(\mathrm{P}_{\mathrm{V}}\right)$ was extracted by using the Normalized Difference Vegetation Index (NDVI) (Equation (2)) [11,38]:

$$
\mathrm{NDVI}=\frac{(\mathrm{NIR}-\mathrm{RED})}{(\mathrm{NIR}+\mathrm{RED})}
$$

where NIR represented Band 4 and Band 5 in Landsat TM and Landsat-8 OLI, respectively, and RED represented Band 3 and Band 4 in Landsat TM and Landsat-8 OLI, respectively.

The $\mathrm{P}_{\mathrm{V}}$ was extracted using Equation (3):

$$
\mathrm{P}_{\mathrm{V}}=\left(\frac{\mathrm{NDVI}-\mathrm{NDVI}_{\min }}{\mathrm{NDVI}_{\min }-\mathrm{NDVI}_{\max }}\right)^{2}
$$

where NDVI was found in Equation (2); the $\mathrm{NDVI}_{\min }$ and $\mathrm{NDVI}_{\max }$ in Equation (3) are the minimum and maximum values of the NDVI, respectively.

The emissivity corrected images were used to calculate LST by using Equation (4) [22]:

$$
\mathrm{LST}=\frac{\mathrm{T}_{\mathrm{B}}}{1+\left(\lambda \times \mathrm{T}_{\mathrm{B}} / \rho\right) \operatorname{In} \varepsilon}
$$

where $T_{B}$ is at-satellite brightness temperature in degrees Kelvin; $\lambda$ is the wavelength of emitted radiance $(\lambda=11.5 \mu \mathrm{m}$ for Landsat TM Band 6 [22] and $\lambda$ is $10.8 \mu \mathrm{m}$ for Landsat TIRS Band 10 [11]; in $\rho=\mathrm{h} \times \mathrm{c} / \sigma\left(1.438 \times 10^{-2} \mathrm{~m} \mathrm{~K}\right), \sigma$ is the Boltzmann constant $\left(1.38 \times 10^{-23} \mathrm{~J} / \mathrm{K}\right), \mathrm{h}$ is the Planck's constant $\left(6.626 \times 10^{-34} \mathrm{~J} \mathrm{~s}\right)$, and $\mathrm{c}$ is the velocity of light $\left(2.998 \times 10^{8} \mathrm{~m} / \mathrm{s}\right) ; \varepsilon$ is the land surface emissivity estimated using the NDVI method [37]. Finally, the extracted LST values (Kelvin) were converted to degrees Celsius $\left({ }^{\circ} \mathrm{C}\right)$. 


\subsection{SUHI Intensity (SUHII) Measurement}

SUHII can be examined based on the landscapes in the selected urban and local climate zone. The magnitude of SUHII can be extracted by comparing the urban-rural temperature difference [7,24]. The authors have adopted two different methods to calculate SUHII for Kandy in 1996, 2006, and 2017: (i) based on the mean LST difference ( $\Delta$ mean LST) of land use/cover categories such as IS and GS; and (ii) based on the mean LST difference ( $\Delta$ mean LST) between urban and rural zones $[7,24]$. Here, SUHII refers to the difference in LST between IS and GS land cover types (local climate zone) (SUHII ${ }_{\text {IS-GS }}$ ) and urban zone and rural zone (SUHII $\left.{ }_{U-R}\right)$ [7]. The calculation of SUHII ${ }_{\text {IS-GS }}$ is simple and requires few steps. It includes extracting the mean LST of the land use/cover categories. Here, we are referring to land use/cover categories such as IS, GS1 and GS2 since other land use/cover categories show only a small proportion of the study area (discussed in Section 2.3). These major land use/cover categories have been used by other studies $[7,9,11,22]$.

Regarding the SUHII $\mathrm{U}_{-\mathrm{R}}, 210$-meter buffer zones (47 zones from the city centre) along the urban-rural gradient were used to calculate the temperature differences between the urban and rural zones $[7,9,11,25]$. Hereafter, mean LST, fraction of IS and GS were extracted based on the above-mentioned urban-rural gradient zone (URZs). Meanwhile, the mean LST, fraction of IS, and GS (GS1 and, GS2) were calculated in each URZ zone.

The magnitude of SUHII ${ }_{\mathrm{U}-\mathrm{R}}$ based on the $\Delta$ mean LST, fraction of IS ( $\Delta$ fraction of IS), and fraction of GS ( $\Delta$ fraction of GS), was calculated based on the methodology proposed by Estoque and Murayama [7]. During this calculation, $\Delta$ mean LST between URZ $_{1}$ was found by subtracting URZs $\left(\mathrm{URZ}_{1}-\mathrm{URZ}_{2} \ldots 47\right)$. The same method was used to calculate the $\Delta$ fraction of IS and $\Delta$ fraction of GS as well. The urban-rural boundary was demarcated by using the fraction of the IS from the city centre zone. The URZ had the highest fraction of IS (urban zone), and the rural boundary was demarcated by using the first URZs zone recoded $<10 \%$ IS fraction (rural zone) from the city centre zone [7].

\subsection{GS/IS Fraction Ratio along the Urban-Rural Gradient}

The GS/IS fraction ratio was calculated based on URZs. The GS/IS fraction ratio was calculated by using Equation (5). The authors have considered only forest as a GS in this analysis:

$$
\text { GSIS fraction ratio }=\left(\frac{\mathrm{GS}_{\mathrm{z}}}{\mathrm{IS}_{\mathrm{z}}}\right)
$$

where "GS" is green space (forest) fraction and "IS" is an impervious surface fraction in URZs (zones 1 to 47$)$.

The GS/IS fraction ratio value less than 1 indicates that a URZ has a higher IS than GS, and a ratio value greater than 1 indicates that a URZ has a higher GS than IS.

The magnitude of the GS/IS fraction ratio was calculated based on the GS/IS fraction ratio for data from 1996, 2006, and 2017. The same method was used to calculate $\Delta$ mean LST in Section 2.5, which was applied to determine the $\Delta$ of GS/IS fraction ratio $\left(\mathrm{URZ}_{1}-\mathrm{URZ}_{2} \ldots 47\right)$.

\section{Results}

\subsection{Land Use/Cover Changes}

The land use/cover maps (Section 2.3) had overall accuracy of $88 \%, 84 \%$, and $90 \%$ in 1996, 2006, and 2017, respectively. Furthermore, a land use/cover map had the Kappa statistic of 0.81 (1996), 0.78 (2006), and 0.86 (2017). To ensure the accuracy of assessment, 640 reference points representing $40 \%$ of the training sample were used to represent all land use classes. Then, Google Earth images were used as reference data to access the accuracy of classified maps [39,40].

Kandy has undergone rapid urbanization during the past two decades (Figure 2a-c). The IS area increased by 982.9 ha during the 1996-2006 period, and it increased 5580.5 ha from 2006 to 2017. 
This indicates that the rapid development of IS areas occurred from 2006 to 2017. The increasing trend in IS areas is highest from 2006-2017 compared to 1996-2017. The annual gain rate of IS was 98 (ha per year) and it increased to 507.3 (ha per year) (Table 3). The GS1 showed a rapid decreasing trend during both time points. The GS2 showed an increasing trend (121 ha per year) from 1996 to 2006. However, GS2 decreased 2971.1 ha (with 204.6 ha per year) (Tables 2 and 3).
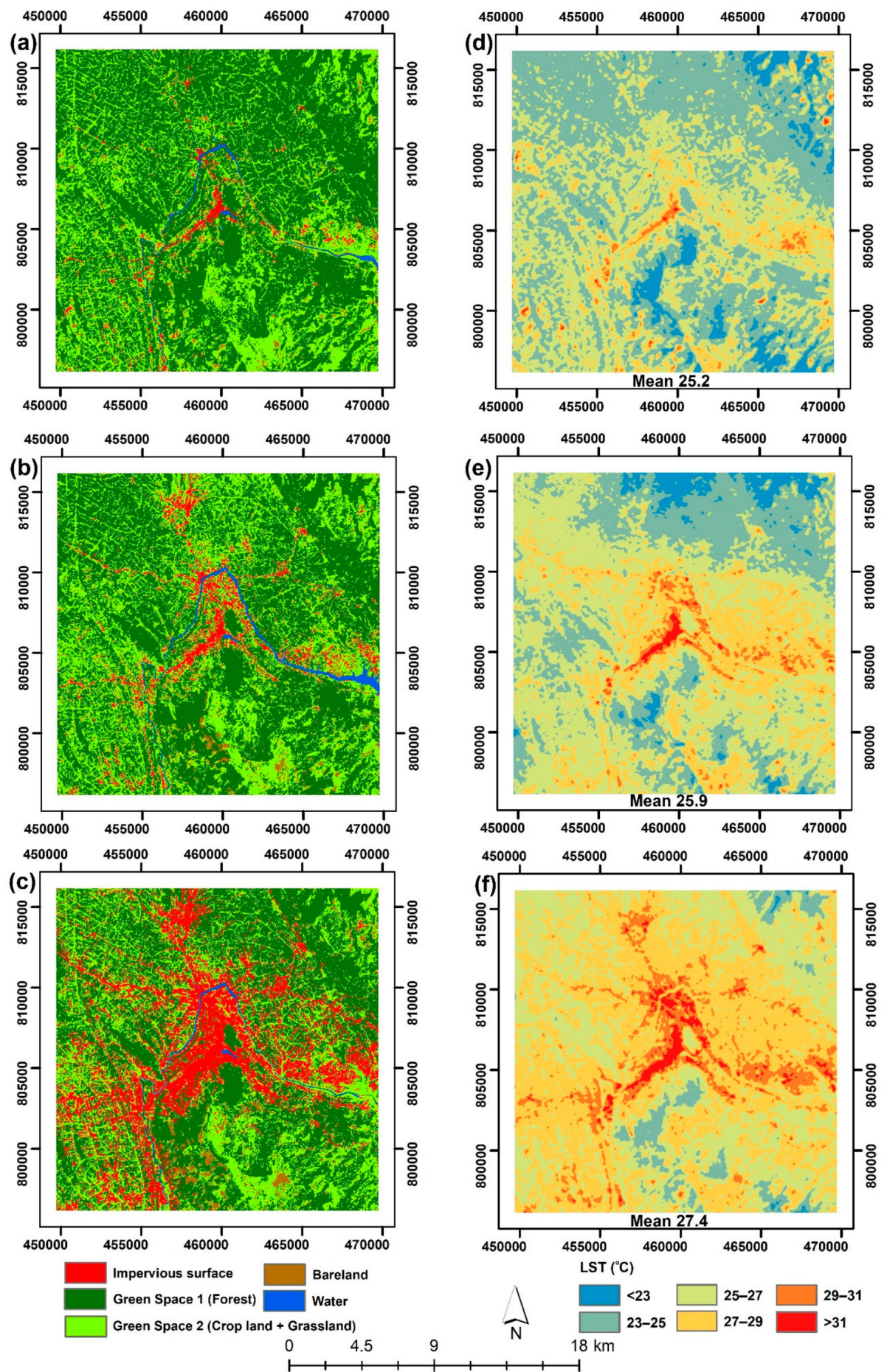

Figure 2. Land use/cover maps and LSTs in Kandy City: (a) land use/cover in 1996; (b) land use/cover in 2006; (c) land use/cover in 2017; (d) LST in 1996; (e) LST in 2006; and (f) LST in 2017. 
Table 2. Details of the land use/cover changes in Kandy City in 1996, 2006, and 2017.

\begin{tabular}{ccccccc}
\hline Land Use/Cover & $\mathbf{1 9 9 6}$ & \multicolumn{2}{c}{$\mathbf{2 0 0 6}$} & \multicolumn{2}{c}{$\mathbf{2 0 1 7}$} \\
\hline & Area (ha) & $\mathbf{\%}$ & Area (ha) & $\mathbf{\%}$ & Area (ha) & $\mathbf{\%}$ \\
\hline Impervious surface & 911.3 & 2.3 & 1894.1 & 4.7 & 7474.6 & 18.7 \\
Green space 1 (forest) & $25,875.1$ & 64.6 & $22,535.0$ & 56.3 & $19,563.9$ & 48.9 \\
Green space 2 (grassland, cropland) & $12,747.9$ & 31.8 & $13,957.8$ & 34.9 & $11,707.0$ & 29.2 \\
Bare land & 222.3 & 0.6 & 1112.8 & 2.8 & 1035.3 & 2.6 \\
Water & 283.5 & 0.7 & 540.3 & 1.3 & 259.2 & 0.6 \\
Total & 40,040 & 100 & 40,040 & 100 & 40,040 & 100 \\
\hline
\end{tabular}

Table 3. Land use/cover changes 1996-2006 and 2006-2017.

\begin{tabular}{ccccccc}
\hline & \multicolumn{2}{c}{ 1996-2006 } & \multicolumn{2}{c}{ 2006-2017 } & \multicolumn{2}{c}{ 1996-2017 } \\
\cline { 2 - 7 } Land Use/Cover & $\begin{array}{c}\text { Land } \\
\text { Use/Cover } \\
\text { Changes (ha) }\end{array}$ & $\begin{array}{c}\text { Annual } \\
\text { Growth Rate } \\
\text { (ha per Year) }\end{array}$ & $\begin{array}{c}\text { Land } \\
\text { Use/Cover } \\
\text { Changes }\end{array}$ & $\begin{array}{c}\text { Annual } \\
\text { Growth Rate } \\
\text { (ha per Year) }\end{array}$ & $\begin{array}{c}\text { Land } \\
\text { Use/Cover } \\
\text { Changes }\end{array}$ & $\begin{array}{c}\text { Annual } \\
\text { Growth Rate } \\
\text { (ha per Year) }\end{array}$ \\
\hline Impervious Surface & 982.8 & 98.3 & 5580.5 & 507.3 & 6563.3 & 312.5 \\
Green space 1 (forest) & -3340.1 & -334.0 & -2971.1 & -270.1 & -6311.2 & -300.5 \\
Green space 2 & 1209.9 & 121.0 & -2250.8 & -204.6 & -1040.9 & -49.6 \\
(grassland, cropland) & 890.5 & 89.1 & -77.5 & -7.0 & 813.0 & 38.7 \\
Bare land & 256.8 & 25.7 & -281.1 & -25.6 & -24.3 & -1.2 \\
Water & & & &
\end{tabular}

\subsection{LST Distribution in Kandy City}

Figure 2d-f show the LST maps of Kandy City in 1996, 2006, and 2017. In 1996, LST ranged between $18.2{ }^{\circ} \mathrm{C}$ and $32.6^{\circ} \mathrm{C}$, with a mean value of $25.2^{\circ} \mathrm{C}$. In 2006 , LST ranged between $19.6^{\circ} \mathrm{C}$ and $36.3^{\circ} \mathrm{C}$, with an increasing the mean LST of $25.9^{\circ} \mathrm{C}$. Overall, mean LST showed an increasing trend for 2017 compared with the last two time points (1996-2006). In 2017, LST ranged between $22.3^{\circ} \mathrm{C}$ and $36.1^{\circ} \mathrm{C}$, with the mean LST of $27.4{ }^{\circ} \mathrm{C}$.

Most of the SUHI accumulated near the city core areas in 1996. By 2006, a similar pattern can be seen due to little development in the city core area. However, a rapid development of the SUHI can be seen in 2017. Most of the city core areas and surrounding areas have been replaced by SUHI. It developed in the northern, eastern, western, and southwestern directions and shows similar patterns of IS areas. Land areas covered with IS had a higher LST, while the land areas covered with GS had lower LSTs at all three time points, as shown in Figure $2 \mathrm{~d}-\mathrm{f}$. The higher temperature areas are becoming more vulnerable to the advanced impact of SUHI in Kandy City.

\subsection{Magnitude and Trend of SUHII}

\subsubsection{SUHIIIS-GS Based on the Cross-Cover Comparison}

The SUHII was calculated based on the major land-use categories and using the cross-cover comparison method [7]. Table 4a shows the mean LST changes based on the IS and GS. It shows that IS always has recorded higher temperatures in comparison with GS. The mean LST increased by $1.3{ }^{\circ} \mathrm{C}$ while the lowest temperature was recorded in GS1 from the three periods. The mean LST of GS1 increased $2{ }^{\circ} \mathrm{C}$ during the last two decades. The results show that mean LST demonstrates an increasing pattern from 1996 to 2017. During these three times, the mean LST of all land-use categories (IS, GS1, and GS2) increased.

Table $4 \mathrm{~b}$ shows the magnitude of the trend of SUHI was high in 2006 compared with the other two times, excluding temperature changes for G2 and G1. The SUHI IS-GS decreased from 2.4 to $2.0^{\circ} \mathrm{C}$ in the period 1996-2017 due to the rising temperature trends in the GS1 and GS2 categories (Table 4a). The average SUHI IS_GS1 was recorded as $2.8^{\circ} \mathrm{C}$ from 1996-2017, showing the highest temperature difference among all land-use categories (Table 4b). 
Table 4. Mean LST of IS and GS and the magnitude and trend of SUHIIIS-GS $\left({ }^{\circ} \mathrm{C}\right)$.

\begin{tabular}{lcccl}
\hline \multicolumn{5}{c}{ (a) Mean LST of IS and GS $\left({ }^{\circ} \mathbf{C}\right)$} \\
\hline Land Use/Cover & $\mathbf{1 9 9 6}$ & $\mathbf{2 0 0 6}$ & $\mathbf{2 0 1 7}$ & Change (2017-1996) \\
\hline IS & 27.7 & 28.4 & 29.0 & 1.3 \\
GS 1 & 24.7 & 25.4 & 26.7 & 2.0 \\
GS 2 & 25.8 & 26.3 & 27.4 & 1.6 \\
GS $^{\text {a }}$ & 25.3 & 25.8 & 27.0 & 1.7 \\
\hline
\end{tabular}

(b) Magnitude and trend of SUHII $\left({ }^{\circ} \mathrm{C}\right)$

\begin{tabular}{lllll}
\hline \multirow{2}{*}{ Land use/cover (cross-cover comparison) } & \multicolumn{3}{l}{ SUHIIIS-GS $(\Delta$ mean LST) } & \multirow{2}{*}{ Average (2017-1996) } \\
\cline { 2 - 4 } & 1996 & 2006 & 2017 & \\
\hline IS-GS 1 & 3.0 & 3.0 & 2.3 & 2.8 \\
IS-GS 2 & 1.9 & 2.1 & 1.6 & 1.9 \\
GS 2-GS 1 & 1.1 & 0.9 & 0.7 & 0.9 \\
IS-GS & 2.4 & 2.6 & 2.0 & 2.3 \\
\hline
\end{tabular}

$\mathrm{GS}^{\mathrm{a}}=$ mean LST of GS ${ }^{\mathrm{a}}$ was calculated by using mean LSTs of GS1 and GS2. The other land use/cover classes were not used in this calculation.

\subsubsection{SUHII $\mathrm{U}_{\mathrm{R}}$ along the Urban-Rural Gradient}

Figure 3a shows the changes in the mean LST, a fraction of GS and IS, along the urban-rural gradient analysis. The highest mean LST was recorded in $\mathrm{URZ}_{1}$ from the city centre, which was $29.6^{\circ} \mathrm{C}$, $32.9^{\circ} \mathrm{C}$, and $33.0^{\circ} \mathrm{C}$ in 1996,2006 , and 2017 , respectively. The mean LST decreased from the city centre to the periphery areas along the URZ. The fraction of IS showed a comparable pattern to the mean LST during the three time points. The fraction of IS showed an increasing trend from the city centre to the periphery areas. The average GS fraction was in a decreasing trend from the city centre of $92.4 \%, 84.9 \%$, and $67.6 \%$, respectively, while there was an increasing trend in IS from $5.7 \%$ in 1996 to $9.9 \%$ in 2006 and $28.8 \%$ in 2017. The regression analysis shows a strong positive relationship between mean LST and fraction of IS and a strong negative relationship between mean LST and fraction of GS (Figure 3b). Additionally, the relationships (the mean LST and the fraction of IS and GS) were statistically significant $(p<0.001)$ in 1996, 2006, and 2017.

(a)
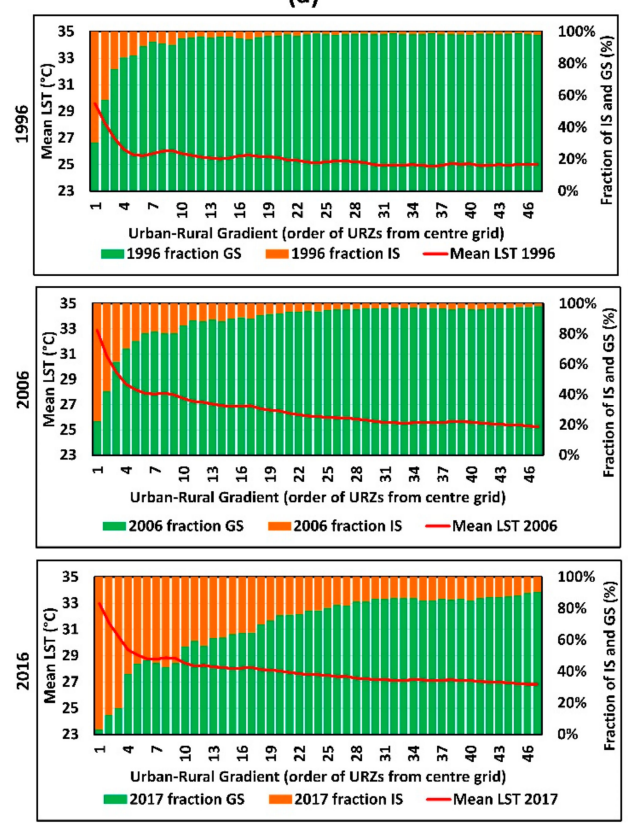

(b)
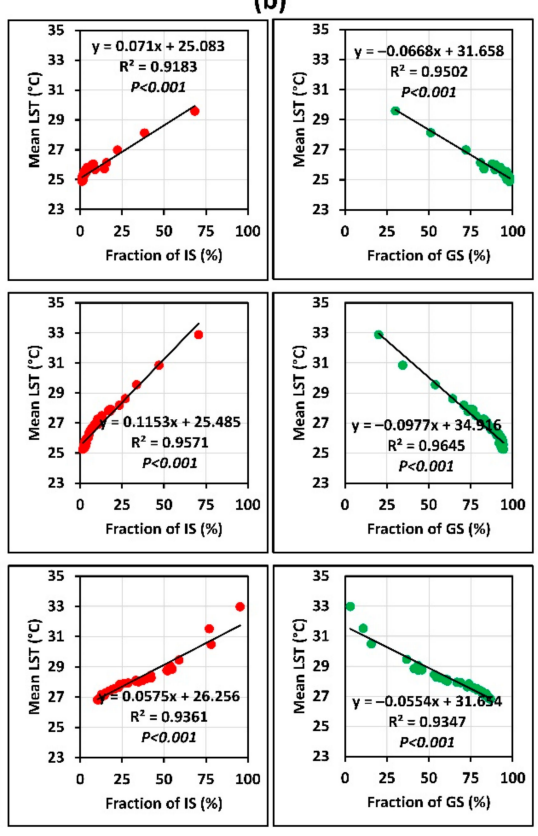

Figure 3. (a) Spatial pattern of mean LST, a fraction of IS and GS along the urban-rural gradient; and (b) scatter plots between mean LST and fraction of IS and GS (here GS includes GS1 and GS2) in Kandy City in 1996, 2006, and 2017. 
Figure 4a shows the magnitude of $\Delta$ mean LST, $\Delta$ fraction of GS and $\Delta$ IS along the URZ. The highest fraction of IS was recorded in URZ $\mathrm{Un}_{1}$ (near city centre zone as $>68 \%,>71 \%$, and $>95 \%$ in 1996,2006 , and 2017, respectively). The urban-rural zone was demarcated by using a $<10 \%$ fraction of IS in comparison with the city centre. The rural zone was demarcated in 1996 as URZ 6 (1.3 km distance from city centre), in 2006 as URZ 13 (2.7 km distance from city centre) and in 2017 as URZ 46 (9.7 km distance from city centre). The magnitude of $\mathrm{SUHII}_{\mathrm{U}-\mathrm{R}}$ was extracted based on the urban and rural demarcation. According to the demarcation, the temperature difference was $3.9^{\circ} \mathrm{C}$ in $1996,5.8^{\circ} \mathrm{C}$ in 2006 , and $6.2^{\circ} \mathrm{C}$ in 2017 . The relationship between the $\Delta$ mean LST and the $\Delta$ fraction IS and GS were statistically significant $(p<0.001)$, and regression analysis indicated a strong positive relationship between $\Delta$ mean LST and $\Delta$ fraction of IS and a strong negative relationship between $\Delta$ mean LST and $\Delta$ fraction of GS (Figure $4 b$ ).

The $\Delta$ mean LST was higher in 2006 compared to 2017 due to the rapid growth in the mean LST in URZ ${ }_{1}$. It increased by $3.3{ }^{\circ} \mathrm{C}$ (from 1996 to 2006). Hence, the $\Delta$ mean LST had a higher magnitude in 2017. In 2017, the URZ 1 zone's mean LST increased by $0.09^{\circ} \mathrm{C}$, compared to 2006 . Moreover, the mean temperature of the surrounding URZ improved in 2017 (Figure 4a).

(a)

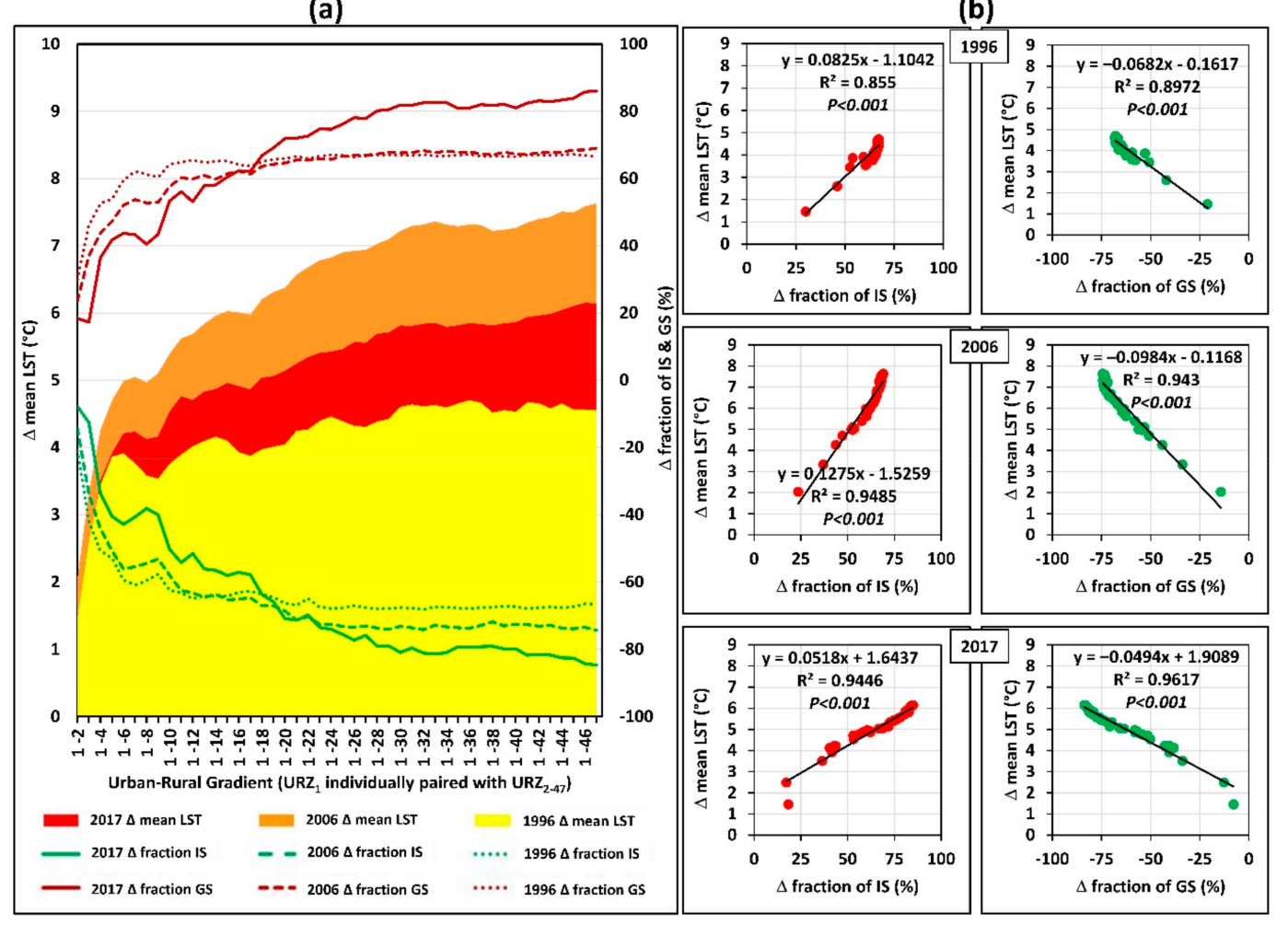

Figure 4. (a) Magnitude of the trend of $\mathrm{SUHII}_{\mathrm{U}-\mathrm{R}}\left({ }^{\circ} \mathrm{C}\right)$, a fraction of IS and GS along the URZ; and (b) scatter plots and statistical relationship between the magnitude of mean LST, fraction of IS, and GS (here GS includes GS1 and GS2) in Kandy City in 1996, 2006, and 2017.

\subsection{GS/IS Fraction Ratio along the Urban-Rural Gradient}

The urbanization in Kandy City shows the forest cover will be more vulnerable to conversion to IS areas in the near future. The forest cover decreased from $64.6 \%$ to $48.9 \%$ between 1996 and 2017 (Table 2), with an annual decreasing rate of 300.5 (ha per year). This shows that forest surface becomes a more important factor for understanding SUHI in Kandy City. Thus, the authors have used the GS/IS fraction ratio to provide meaningful results to policymakers and urban planners.

Figure 5 shows the relationship between mean LST and the GS/IS fraction ratio along the URZ. The GS/IS fraction ratio rapidly declined from 1996 to 2017. The maximum GS/IS fraction ratio 
decreased from 1996 to 2017 considerably. It decreased by 49.5 (1996-2006) and 29.2 (2006-2017) and overall 78.7 (1996-2017), which caused an increase in the mean LST from $25.5^{\circ} \mathrm{C}$ to $27.9^{\circ} \mathrm{C}$ (1996-2017). The GS/IS fraction ratio has a strong negative relationship to the mean LST. The coefficient of determination $\left(R^{2}\right)$ value increased by $0.52,0.62$, and 0.61 in 1996,2006 , and 2017 , respectively.

The result indicates that the rapid development of the IS in Kandy City negatively affected the trend of the GS/IS fraction ratio. The green area plays a vital role in minimizing the SUHI in the urban and surrounding areas. Concerning 1996 and 2006, only zones 1 and 2 indicated the GS/IS fraction ratio of less than 1 . However, in 2017 , it shifted to a $2.7 \mathrm{~km}$ distance from the city centre (URZ $\left.\mathrm{U}_{13}\right)$. This shows IS areas were increasing toward the periphery areas from the city centre. It was directly affected by the formation of SUHI.

(a)

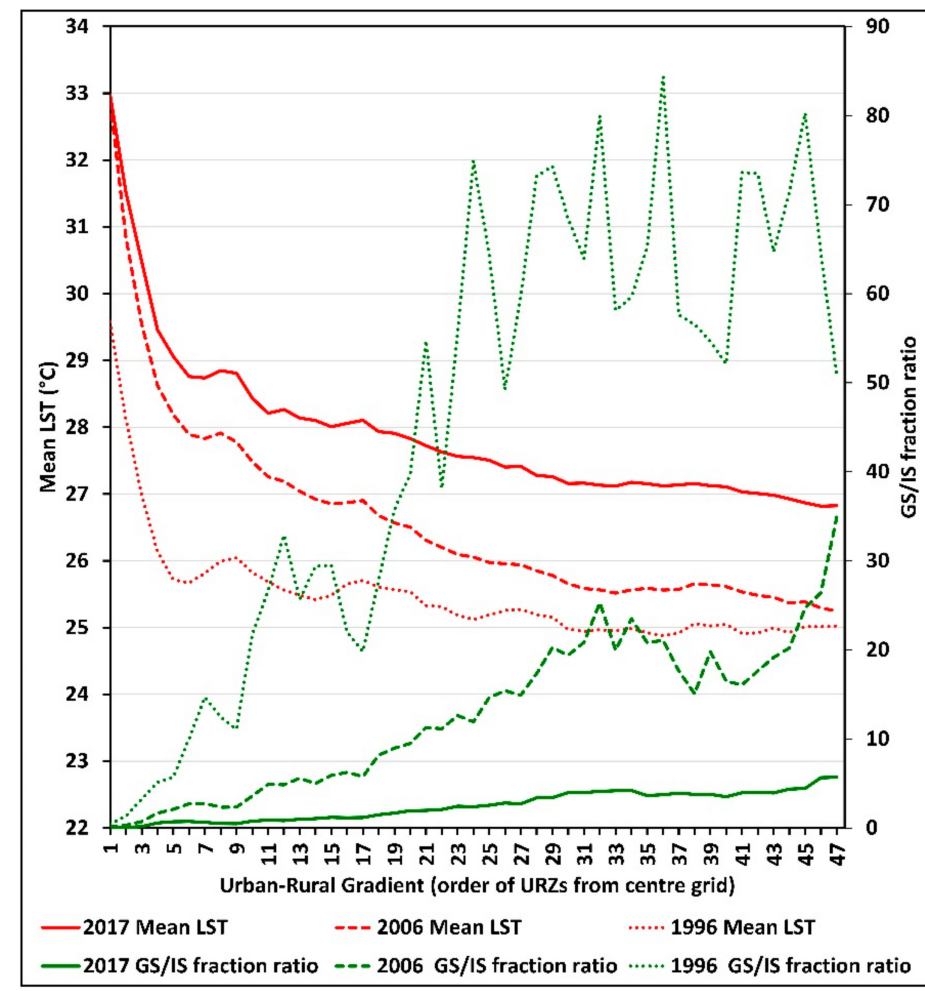

(b)
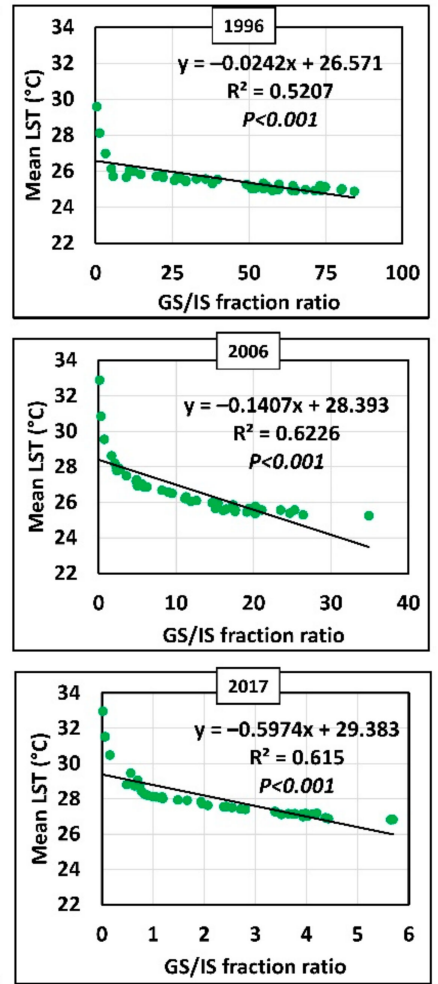

Figure 5. (a) Spatial pattern of the mean LST, GS/IS fraction ratio along the urban-rural gradient; and (b) scatter plots between mean LST and the GS/IS fraction ratio (here GS includes forest only) of Kandy City in 1996, 2006 and 2017.

Figure 6a shows the magnitude of $\Delta$ mean LST and the $\Delta$ fraction of GS/IS ratio along the urban-rural gradient analysis. The maximum $\Delta \mathrm{GS} / \mathrm{IS}$ fraction ratio was recorded in URZ 36 in 1996. During 2006 and 2017 it shifted to URZ 47 . The $\Delta$ mean LST shows $4.7^{\circ} \mathrm{C}, 7.6^{\circ} \mathrm{C}$, and $6.1^{\circ} \mathrm{C}$ in 1996 , 2006, and 2017, respectively. This indicates that the maximum $\Delta$ GS/IS fraction ratio recorded in URZs were subjected to record high $\Delta$ mean LSTs. The result indicates that a $\Delta$ GS/IS fraction ratio plays a vital role in the formation of SUHI in Kandy City. The relationship between the $\Delta$ mean LST and the $\Delta \mathrm{GS} / \mathrm{IS}$ fraction ratio was statistically significant $(p<0.001)$, and regression analysis indicated a strong negative relationship between the $\Delta$ mean LST and the $\Delta$ GS/IS fraction ratio (Figure $6 \mathrm{~b}$ ). 
(a)

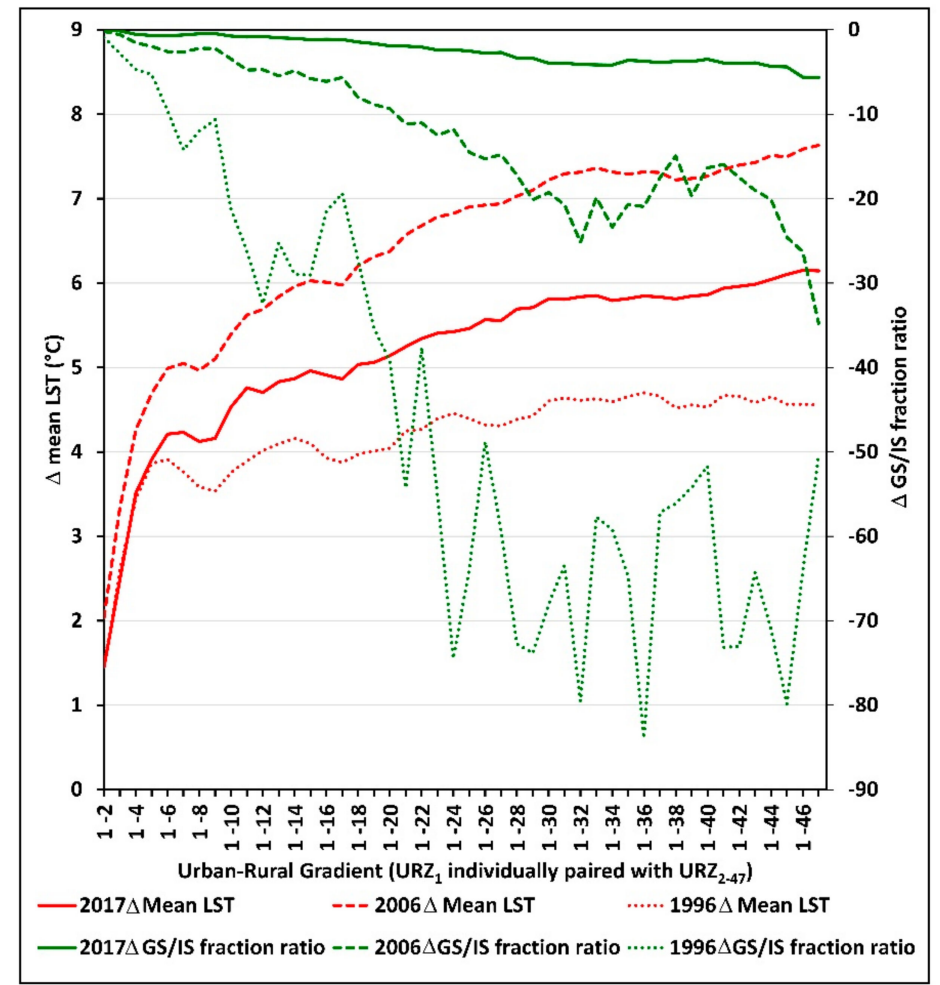

(b)
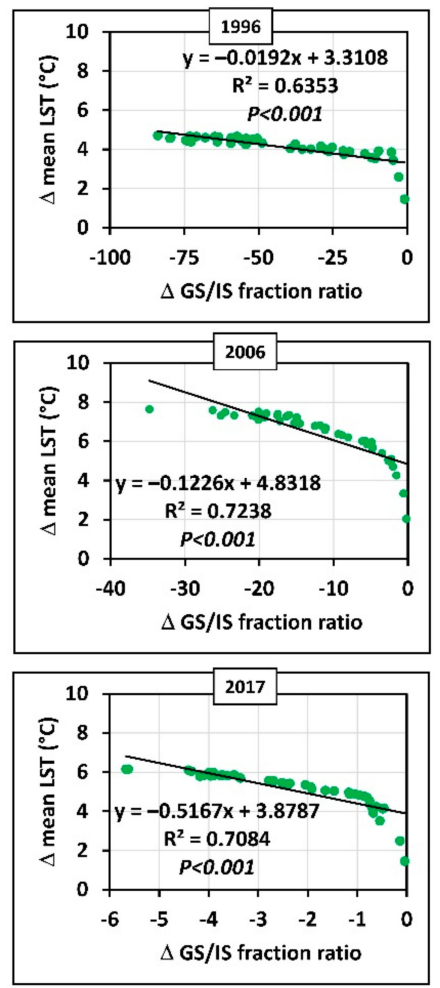

Figure 6. (a) Magnitude of the trend of SUHII ${ }_{U-R}\left({ }^{\circ} \mathrm{C}\right)$, a GS/IS fraction ratio along the URZ; and (b) scatter plots and statistical relationship between the magnitude of LST and the GS/IS fraction ratio of Kandy City in 1996, 2006, and 2017.

\section{Discussion}

\subsection{The Urbanization and Its Impact on Kandy City}

Urbanization provides better social and economic living conditions to the people, but also causes severe impacts on the environment $[5,6]$. The results show that Kandy City has undergone rapid urban development, especially from 2006 to 2017. There are a significant number of IS areas in the central business district (CBD) of the city in 1996, 2006, and 2017. Most of the urban development of Kandy City can be seen in the north, east, and southwestern directions of the city in 2017 (Figure 2c). During the 1996-2006 period, IS was recorded as 982.8 ha (98.3 ha per year), which increased up to 6563.3 ha (312.5 ha per year) in 2017 (Tables 2 and 3). It can be seen that urban development rapidly increased notably from 2006 to 2017. Subsequently, the green areas were decreased due to rapid urban expansion. Consequently, most forest areas were replaced by IS. The loss rate of the annual forest cover was 300.5 ha per year from 1996 to 2017. Generally, an urban area, such as impervious surfaces, reflects more solar radiation than the vegetated areas, and this "heat back to the atmosphere process" results in increasing urban heat stress in urban areas [41]. These results show that IS had a high mean LST (Table 4a) in comparison with other land-use categories. Previous studies also show similar results $[9,11,38]$.

Figure 7 shows that the population of Kandy District has been increasing continuously. The population of Kandy District was 1,375,382, accounting for more than $53 \%$ of the population in the Central Province (which consists of Kandy, Matale and Nuwara Eliya) in 2012 [42]. Population projections revealed that the population of Kandy District would increase, and the increase would play a vital role in the urbanization process of Kandy District. The rapid population growth will change more natural land into IS to facilitate housing and the zoning plan [8], which will heavily affect the 
SUHI phenomenon in the future. Hence, green planning is needed to minimize the negative impacts of the SUHI in Kandy City.

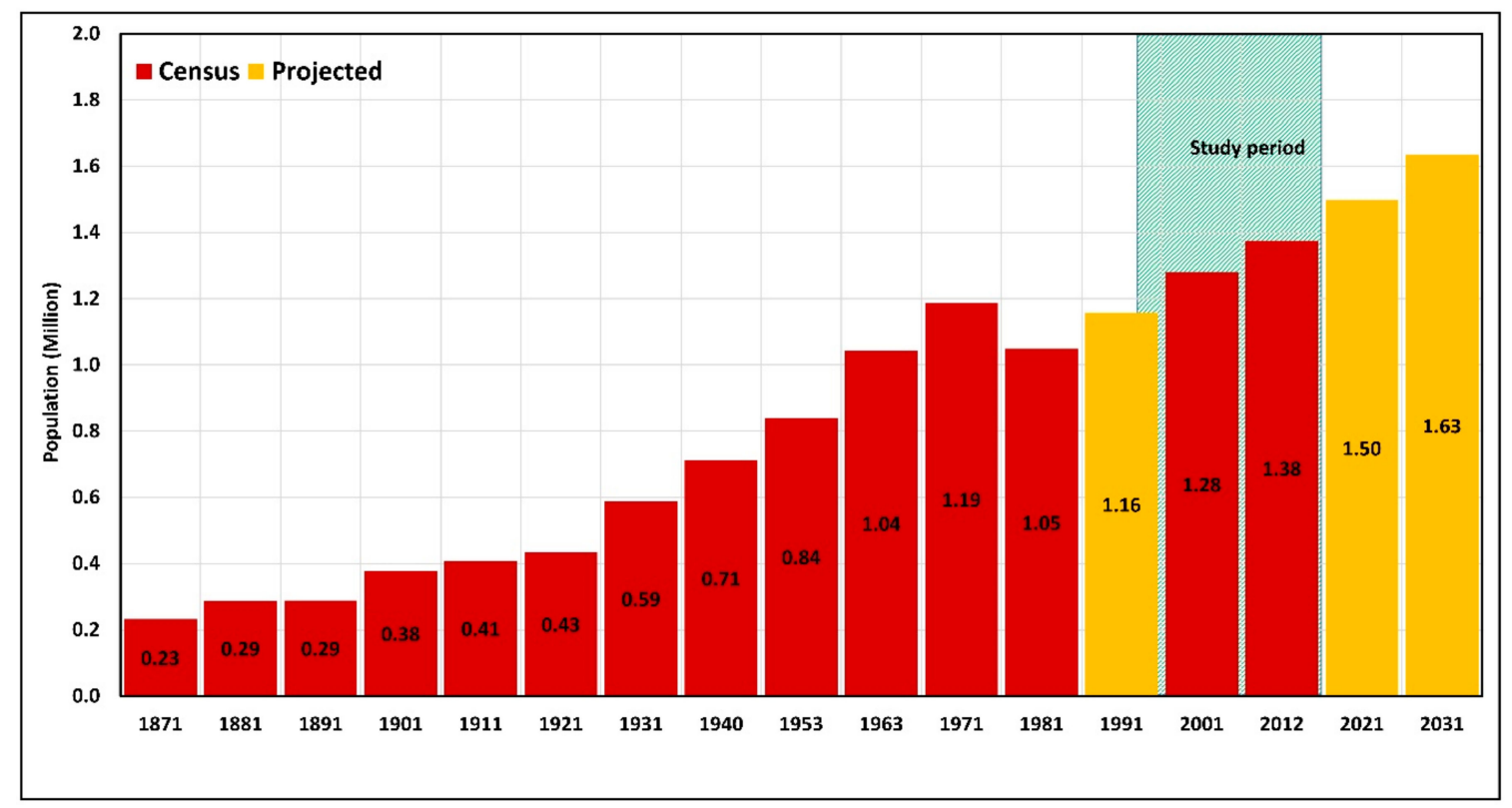

Figure 7. Population growth of Kandy District. Note: The 1991 population was projected by using a $1.0 \%$ growth rate (1981-2001). The populations of 2021, 2031, and 2041 were projected by using a $0.9 \%$ growth rate (average between 1981-2001 and 2001-2012). Data source: Department of Census and Statistics, Sri Lanka, 2012.

The increasing energy consumption is one of the significant adverse impacts of SUHI [2,12]. The increase in energy demand for cooling (such as air conditioning and fans) will add considerable pressure to the energy supply [2,43]. Figure 8 shows the electricity consumption of the central province of Sri Lanka. It indicates that the energy consumption was in an increasing trend with an annual rate of 7\% (1996-2017). The future years (2018-2031) are predicted based on the increasing annual rate. It is notable that electricity consumption will be a greater challenge in the future due to the increase in the SUHI of the study area. The policymakers and urban planners need to pay much more attention to introducing proper mitigation measures to minimize the advancing impact of SUHI [8], such as controlling energy consumption, especially in urban areas.

\subsection{SUHI Intensity and Its Effects}

The rapid urban landscape changes in Kandy City and its neighbouring areas affect the increasing trend of SUHI magnitude. The high $\Delta$ mean LST has been recorded in IS during three periods and compared to the differences in GS1 and GS2 (Table 2b). The average $\Delta$ mean LST value between IS and GS $\left(2.3^{\circ} \mathrm{C}\right)$ and IS and GS1 $\left(2.8^{\circ} \mathrm{C}\right)$ was observed. The result of this study is similar to the findings of Baguio City (mountain city) in the Philippines [7]. Additionally, the results of this study are comparable to tropical low land coastal cities like Jakarta $\left(2.9^{\circ} \mathrm{C}\right)$, Bangkok $\left(2.2^{\circ} \mathrm{C}\right)[11]$, and Guangzhou $\left(2.8^{\circ} \mathrm{C}\right)$ [44]. These changes in $\Delta$ mean LST will intensify the impact of SUHI on the population of Kandy City.

The highest mean LST value was recorded in the zones near the city centre during three periods (Figure 3). A higher IS and lower GS fraction occurred near the city centre zones where the highest mean LST value was recorded. The IS and GS fractions have been statistically significant for three timeframes $(p<0.001)$. The IS fraction was positively correlated with the mean LST, and the $R^{2}$ value was $0.91,0.95$, and 0.93 in 1996, 2006, and 2017, respectively, while the GS fraction was negatively correlated with the mean LST, and the $\mathrm{R}^{2}$ value showed a high negative relationship in three different 
years. The results of this study are similar to the findings of Beijing, China [26] and Bangkok, Jakarta, and Manila [11].

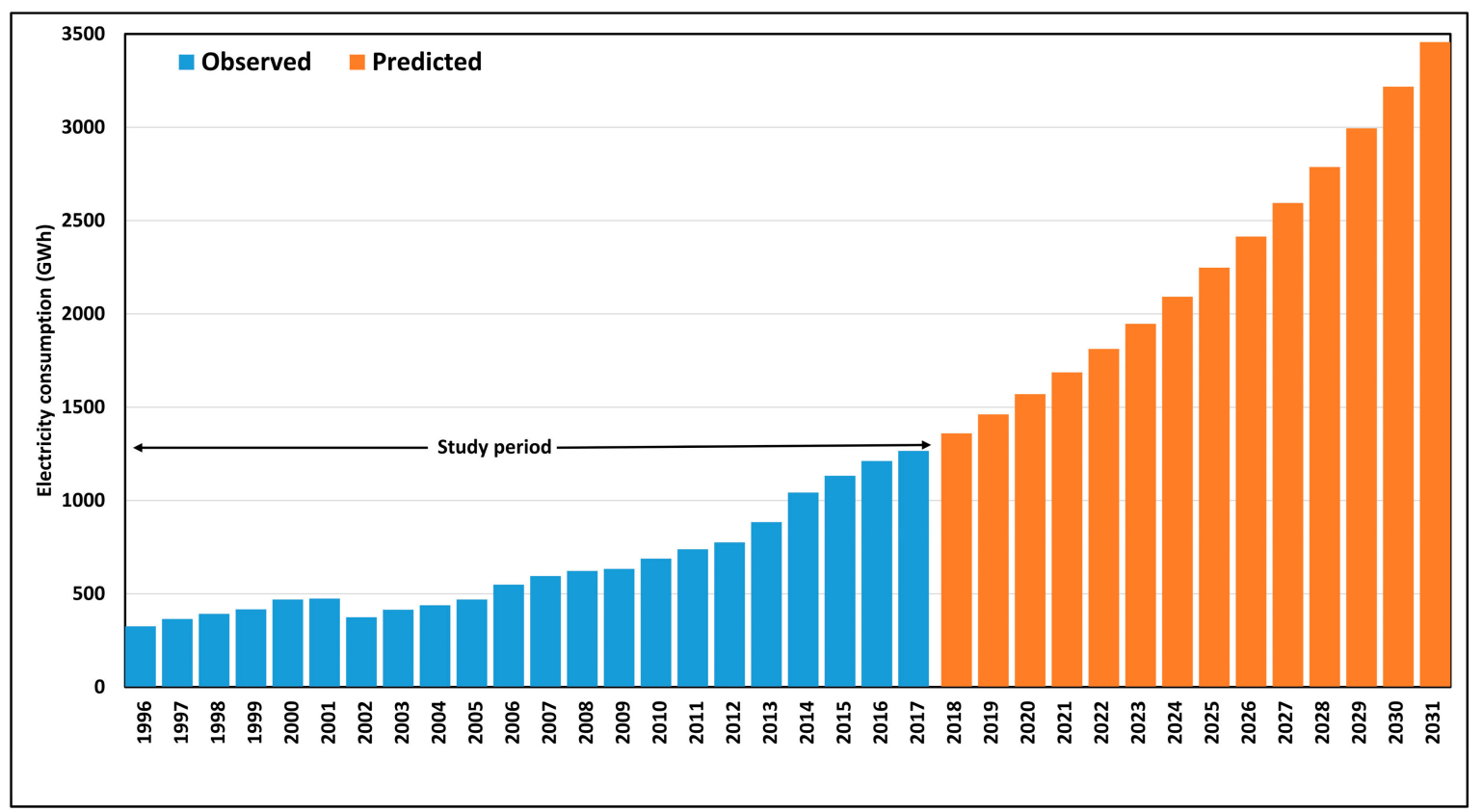

Figure 8. Electricity consumption in the central province of Sri Lanka. Note: The consumption from 2018 to 2031 is projected by using a 7\% growth rate (1996-2017). Data source: Sri Lanka Electricity Board, Sri Lanka, 2017.

There is a decreasing trend in the mean LST from the city centre to rural areas from 1996 to 2017. The spatial profile of SUHI always follows the fraction of the IS and GS distribution (Figure 3). The IS fraction increased from the city centre to the rural areas, while GS decreased and a high LST value was recorded in 2017. Additionally, the average mean LST of the IS fraction had an increasing trend, while the average mean LST of the GS fraction was in a declining trend. The mean LST was recorded as $25.5,26.69$, and 27.9 ; the average fraction of IS was $5.7 \%, 9.9 \%$, and $28.8 \%$; and the average fraction of GS was $92.4 \%, 84.9 \%$, and $67.6 \%$ for 1996, 2006 and 2017, respectively. This is important evidence for measuring the landscape changes in Kandy City during the study period, and this shows a direct effect on the SUHI phenomenon. The more natural land has been converted to IS to facilitate the rapid urban development of the city. A similar pattern was observed in previous studies [11,22,26].

The SUHII of Kandy City declined from 1996 to 2017 (Table 4b and Figure 4). The magnitude of LST along the URZ increased. The rural zones (recorded as a $<10 \%$ fraction of IS) shifted in distance from the city centre as $\mathrm{URZ}_{6}\left(1.3 \mathrm{~km}\right.$ from the city centre), $\mathrm{URZ}_{13}(2.7 \mathrm{~km}$ from the city centre) and URZ $_{46}(9.7 \mathrm{~km}$ from the city centre) in 1996, 2006 and 2017, respectively. The shifting urban-rural zone (IS fraction $<10 \%$ ) shows the rapid urban development of the study area from rural areas. These buffer zones are more vulnerable to occurring SUHI effects.

\subsection{Implications for Urban Sustainability}

The urbanization in Kandy City shows that most of the vegetated areas have been converted to IS areas during the last 21 years. IS is profoundly affected by the increase in SUHI in urban areas due to the direct reflectance of solar radiation [2,7]. GS plays a vital role in reducing SUHI effects in the urban areas [2]. Furthermore, GS, such as forest, cropland, and grassland, can improve the air quality in urban areas. They act as "lungs" for an urban area by proving oxygen and absorbing harmful air pollution [7]. Hence, the GS/IS fraction ratio provides a better understanding of the distribution of GS and IS along the urban-rural gradient. 
The average GS/IS fraction ratio was 44.7, 20.4, and 3.9 in 1996, 2006, and 2017, respectively. The GS/IS fraction ratio was statistically significant $(p<0.001)$ and correlated negatively with the mean LST at three time points. This indicates that the GS/IS fraction ratio becomes an essential factor for controlling the LST in Kandy City (Figure 5). The higher $\Delta$ mean LST was recorded in the same URZs that had higher GS/IS fraction ratios (Figure 6). It clearly shows that the $\Delta$ GS/IS fraction ratio played a vital role in encapsulating the SUHII. The $\Delta$ mean LST and the $\Delta$ GS/IS fraction ratio had a strong negative correlation in the three different years. GS can contribute to improvement of the thermodynamic properties of the urban area by providing cooling and circulation of air [45]. Thus, GS plays a significant role in reducing the SUHI effects in urban areas. Previous studies show that green cover acts to decrease the LST [27]. Therefore, the urban policymakers of Kandy City and the Urban Development Authority (UDA) need to consider increasing green areas, especially in the surrounding areas of Kandy City, which will help to increase the GS/IS fraction ratio. Prior to providing policies to enhance the green cover of the city, it is important to protect every single tree currently existing. The policy needs to be more focused on protecting remaining green areas inside Kandy City, as well as building with green roofs, green buildings, urban agriculture, green parks, and tree planting along the main roads and government buildings $[7,8,11,13]$, which will help to improve the GS/IS fraction ratio of the city.

The SUHI effect increased from 1996 to 2017 in the study area (Figure 4). The land cover with IS was, on average, $2.3^{\circ} \mathrm{C}$ hotter than land cover with GS (1996-2017) (Table 1). Additionally, lands in $\mathrm{URZ}_{1}$ were, on average, $5.3^{\circ} \mathrm{C}$ hotter than the land area in the rural zone (URZs fraction $<10 \%$ ) from the city centre (Figure 4). This result indicates that "fraction of IS" is a vital factor for increasing mean LST. The rapidly increasing trend of the mean LST in urban areas has resulted in the occurrence of SUHI [7]. The dominant population and their social and economic activities occur in the urban area, where there is a high "IS" fraction. The rapid changes in "IS" show population growth as well. Hence, the population living in this area is becoming exposed to the greater impact of SUHI, such as a weakening of the living environment [12], impaired water quality and compromised human health and comfort $[2,11]$. Policymakers need to consider a green planning concept for improving the urban environment.

There are several ways to mitigate the UHI effects of the study area. The urban greening concept could be utilized in future urban planning, and existing green areas also need to be protected inside the city. The green belt concept can be applied along the main roads and at schools, hospitals, and government buildings. The buildings with green walls are one of the alternative methods of increasing the green areas inside the city limits. Previous research has shown that green walls were capable of declining indoor temperatures by $2.4^{\circ} \mathrm{C}$ [46]. The authors firmly believe that the existing urban policies are not sufficient for enhancing the urban greening concept of this city. Most of the unplanned development has experienced the same profound SUHI effects as Kandy City. Urban policy should be developed based on the SUHI and its adverse impacts. The authors hope that this study can provide sufficient ways to mitigate SUHI. The findings of this study can help to reorient the current urban policies toward the perspective of urban sustainability in the tropical mountain city of Kandy.

The use of more images captured in the same year will provide more information, resulting in a much stronger spatiotemporal analysis. The availability of cloud-free usable images has been constrained in this study. Thus, we have selected 1996, 2006, and 2017 as the timeframes of the study. The acquisition time of the three satellite images might have an influence on the result. In addition to that, several environmental factors such as wind speed, surface moisture, humidity, and intensity of solar radiation could influence the LST during the different years [7,13]. However, this study used relative LST difference over the three years, rather than the absolute temperature. Thus, it is recommended that the results be interpreted in light of these limitations. 


\section{Conclusions}

This study shows that Kandy City and the surrounding areas were affected by the formation of SUHIs from 1996 to 2017 . The $\Delta$ mean LST of $3.9^{\circ} \mathrm{C}$ (1996) increased to $6.2^{\circ} \mathrm{C}$ (2017) based on the urban-rural zones. The observed increasing trend of SUHII is associated with the rapid urban development of Kandy. The cross-cover comparison result shows that $\Delta$ mean LST is always higher for IS compared to GS1 and GS2. The urbanization pattern shows that the urban-rural zone ( $<10$ IS) along the URZ has shifted from $\mathrm{URZ}_{6}(1.3 \mathrm{~km})$ to $\mathrm{URZ}_{46}(9.7 \mathrm{~km})$ from 1996 to 2017. In addition, the GS/IS fraction ratio declined rapidly from 1996 to 2017. The GS/IS fraction ratio was recorded as 44.7 in 1996 and had declined to 3.9 by 2017. The GS/IS fraction ratio can be considered as a proxy indicator for identifying the formation of SUHI in the study areas. The policymakers and urban planners need to seriously think about utilizing the GS/IS fraction ratio to overcome the negative impacts of SUHI. The development of green areas is one way to overcome the rapid changes in the thermal environment of Kandy. The results of this study will help to identify the formation of SUHI in Kandy City. The policymakers and urban planners need to consider the introduction of proper mitigation measures to overcome the impact of SUHI. We would like to recommend that an urban greening concept be considered to control the SUHI effects. Overall, the findings of this study could be used as a proxy indicator in the landscape and urban planning for the World Heritage City of Kandy.

Author Contributions: The corresponding author, M.R., proposed the topic and spearheaded the data processing and analysis, as well as the writing of the manuscript. D.D., Y.M., X.Z., R.C.E., E.P., and T.M. helped in the design, research implementation and analysis and writing of the manuscript.

Funding: This study was supported by the Japan Society for the Promotion of Science (JSPS) through Grant-in-Aid for Challenging Exploratory Research 16K12816 and Scientific Research (B) 18H00763.

Acknowledgments: The authors express their gratefulness to the Sri Lanka Electricity Board, Department of Census and Statistics and the Department of Meteorology, Sri Lanka, for providing the data for this study. The comments and suggestions of the anonymous reviewers are gratefully acknowledged.

Conflicts of Interest: The authors declare no conflict of interest.

\section{References}

1. Voogt, J.A.; Oke, T.R. Thermal remote sensing of urban climates. Remote Sens. Environ. 2003, 86, 370-384. [CrossRef]

2. EPA (US Environmental Protection Agency). Reducing Urban Heat Islands: Compendium of Strategies. Available online: https: / www.epa.gov/sites/production/files/2014-06/documents/basicscompendium. pdf (accessed on 20 June 2018).

3. Kikon, N.; Singh, P.; Singh, S.K.; Vyas, A. Assessment of urban heat islands (UHI) of Noida City, India using multi-temporal satellite data. Sustain. Cities Soc. 2016, 22, 19-28. [CrossRef]

4. Oke, T.R. City size and the urban heat island. Atmos. Environ. (1967) 1973, 7, 769-779. [CrossRef]

5. Estoque, R.C.; Murayama, Y. Measuring sustainability based upon various perspectives: A case study of a hill station in Southeast Asia. Ambio 2014, 43, 943-956. [CrossRef] [PubMed]

6. Estoque, R.C.; Murayama, Y. Quantifying landscape pattern and ecosystem service value changes in four rapidly urbanizing hill stations of Southeast Asia. Landsc. Ecol. 2016, 31, 1481-1507. [CrossRef]

7. Estoque, R.C.; Murayama, Y. Monitoring surface urban heat island formation in a tropical mountain city using Landsat data (1987-2015). ISPRS J. Photogramm. Remote Sens. 2017, 133, 18-29. [CrossRef]

8. Ranagalage, M.; Estoque, R.C.; Murayama, Y. An urban heat island study of the Colombo Metropolitan Area, Sri Lanka, based on landsat data (1997-2017). ISPRS Int. J. Geo-Inf. 2017, 6, 189. [CrossRef]

9. Myint, S.W.; Brazel, A.; Okin, G.; Buyantuyev, A. Combined effects of impervious surface and vegetation cover on air temperature variations in a rapidly expanding desert city. GISci. Remote Sens. 2010, 47, 301-320. [CrossRef]

10. Xu, H.; Lin, D.; Tang, F. The impact of impervious surface development on land surface temperature in a subtropical city: Xiamen, China. Int. J. Climatol. 2013, 33, 1873-1883. [CrossRef] 
11. Estoque, R.C.; Murayama, Y.; Myint, S.W. Effects of landscape composition and pattern on land surface temperature: An urban heat island study in the megacities of Southeast Asia. Sci. Total. Environ. 2017, 577, 349-359. [CrossRef] [PubMed]

12. Rizwan, A.M.; Dennis, L.Y.C.; Liu, C. A review on the generation, determination and mitigation of Urban Heat Island. J. Environ. Sci. 2008, 20, 120-128. [CrossRef]

13. Ranagalage, M.; Estoque, R.C.; Zhang, X.; Murayama, Y. Spatial changes of urban heat island formation in the Colombo District, Sri Lanka: Implications for sustainability planning. Sustainability 2018, 10, 1367. [CrossRef]

14. Sakakibara, Y.; Owa, K. Urban-rural temperature differences in coastal cities: Influence of rural sites. Int. J. Climatol. 2005, 25, 811-820. [CrossRef]

15. Bokaie, M.; Zarkesh, M.K.; Arasteh, P.D.; Hosseini, A. Assessment of urban heat island based on the relationship between land surface temperature and land use/land cover in Tehran. Sustain. Cities Soc. 2016, 23, 94-104. [CrossRef]

16. Estoque, R.C.; Murayama, Y. City Profile: Baguio. Cities 2013, 30, 240-251. [CrossRef]

17. Chen, X.; Zhang, Y. Impacts of urban surface characteristics on spatiotemporal pattern of land surface temperature in Kunming of China. Sustain. Cities Soc. 2017, 32, 87-99. [CrossRef]

18. Chen, X.L.; Zhao, H.M.; Li, P.X.; Yin, Z.Y. Remote sensing image-based analysis of the relationship between urban heat island and land use/cover changes. Remote Sens. Environ. 2006, 104, 133-146. [CrossRef]

19. Oke, T.R. The energetic basis of the urban heat island. Q. J. R. Meteorol. Soc. 1982, 108, 1-24. [CrossRef]

20. Arnfield, A.J. Two decades of urban climate research: A review of turbulence, exchanges of energy and water, and the urban heat island. Int. J. Climatol. 2003, 23, 1-26. [CrossRef]

21. Gunaalan, K.; Ranagalage, M.; Gunarathna, M.H.J.P.; Kumari, M.K.N.; Vithanage, M.; Srivaratharasan, T.; Saravanan, S.; Warnasuriya, T.W.S. Application of geospatial techniques for groundwater quality and availability assessment: A case study in Jaffna Peninsula, Sri Lanka. ISPRS Int. J. Geo-Inf. 2018, 7, 20. [CrossRef]

22. Weng, Q.; Lu, D.; Schubring, J. Estimation of land surface temperature-vegetation abundance relationship for urban heat island studies. Remote Sens. Environ. 2004, 89, 467-483. [CrossRef]

23. Oke, T.R. Initial Guidance to Obtain Representative Meteorological Observations at Urban Sites. Available online: http:/ /blogs.ubc.ca/toke/files/2015/12/IOM-81-UrbanMetObs.pdf (accessed on 20 June 2018).

24. Stewart, I.; Oke, T. Classifying Urban Climate Field Sites by "Local Climate Zones": The Case of Nagano, Japan. Available online: http:/ / www.ide.titech.ac.jp/ icuc7/extended_abstracts/pdf/385055-1090515165722-002.pdf (accessed on 20 June 2018).

25. Ranagalage, M.; Estoque, R.C.; Handayani, H.H.; Zhang, X.; Morimoto, T.; Tadono, T.; Murayama, Y. Relation between urban volume and land surface temperature: A comparative study of planned and traditional cities in Japan. Sustainability 2018, 10, 2366. [CrossRef]

26. Xiao, R.; Ouyang, Z.; Zheng, H.; Li, W.; Schienke, E.W.; Wang, X. Spatial pattern of impervious surfaces and their impacts on land surface temperature in Beijing, China. J. Environ. Sci. 2007, 19, 250-256. [CrossRef]

27. Li, X.; Zhou, W.; Ouyang, Z.; Xu, W.; Zheng, H. Spatial pattern of greenspace affects land surface temperature: Evidence from the heavily urbanized Beijing metropolitan area, China. Landsc. Ecol. 2012, 27, 887-898. [CrossRef]

28. Senanayake, I.P.; Welivitiya, W.D.D. P.; Nadeeka, P.M. Remote sensing based analysis of urban heat islands with vegetation cover in Colombo city, Sri Lanka using Landsat-7 ETM+ data. Urban Clim. 2013, 5, 19-35. [CrossRef]

29. Meetiyagoda, L. Pedestrian safety in Kandy Heritage City, Sri Lanka: Lessons from World Heritage Cities. Sustain. Cities Soc. 2018, 38, 301-308. [CrossRef]

30. UNESCO. Available online: https://whc.unesco.org/en/list/450 (accessed on 15 June 2018).

31. Weerasundara, L.; Amarasekara, R.W.K.; Magana-Arachchi, D.N.; Ziyath, A.M.; Karunaratne, D.G.G.P.; Goonetilleke, A.; Vithanage, M. Microorganisms and heavy metals associated with atmospheric deposition in a congested urban environment of a developing country: Sri Lanka. Sci. Total Environ. 2017, 584-585, 803-812. [CrossRef] [PubMed]

32. Department of Meteorology Sri Lanka. Available online: http://www.meteo.gov.lk/index.php?option= com_content\&view=article\&id=94:climate-of-sri-lanka\&catid=20\&lang=en\&Itemid=310 (accessed on 16 June 2018). 
33. Liu, K.; Su, H.; Zhang, L.; Yang, H.; Zhang, R.; Li, X. Analysis of the urban heat Island effect in Shijiazhuang, China using satellite and airborne data. Remote Sens. 2015, 7, 4804-4833. [CrossRef]

34. Sanchez-Hernandez, C.; Boyd, D.S.; Foody, G.M. Mapping specific habitats from remotely sensed imagery: Support vector machine and support vector data description based classification of coastal saltmarsh habitats. Ecol. Inform. 2007, 2, 83-88. [CrossRef]

35. Petropoulos, G.P.; Kontoes, C.; Keramitsoglou, I. Burnt area delineation from a uni-temporal perspective based on landsat TM imagery classification using Support Vector Machines. Int. J. Appl. Earth Obs. Geoinf. 2011, 13, 70-80. [CrossRef]

36. Singh, S.K.; Srivastava, P.K.; Gupta, M.; Thakur, J.K.; Mukherjee, S. Appraisal of land use/land cover of mangrove forest ecosystem using support vector machine. Environ. Earth Sci. 2014, 71, 2245-2255. [CrossRef]

37. Sobrino, J.A.; Jiménez-Muñoz, J.C.; Paolini, L. Land surface temperature retrieval from landsat TM 5. Remote Sens. Environ. 2004, 90, 434-440. [CrossRef]

38. Zhang, X.; Estoque, R.C.; Murayama, Y. An urban heat island study in Nanchang City, China based on land surface temperature and social-ecological variables. Sustain. Cities Soc. 2017, 32, 557-568. [CrossRef]

39. Estoque, R.C.; Murayama, Y.; Akiyama, C.M. Pixel-based and object-based classifications using high- and medium-spatial-resolution imageries in the urban and suburban landscapes. Geocarto Int. 2015, 30, 1113-1129. [CrossRef]

40. Ye, S.; Pontius, R.G.; Rakshit, R. A review of accuracy assessment for object-based image analysis: From per-pixel to per-polygon approaches. ISPRS J. Photogramm. Remote Sens. 2018, 141, 137-147. [CrossRef]

41. Trusilova, K.; Jung, M.; Churkina, G. On climate impacts of a potential expansion of urban land in Europe. J. Appl. Meteorol. Climatol. 2009, 48, 1971-1980. [CrossRef]

42. Department of Census and Statistics. Census of Population and Housing 2012. Available online: http:/ / www. statistics.gov.lk/PopHouSat/CPH2011/Pages/Activities/Reports/CPH_2012_5Per_Rpt.pdf (accessed on 16 June 2018).

43. Igun, E. Analysis and sustainable management of urban growth's impact on land surface temperature in Lagos, Nigeria. J. Remote Sens. GIS 2017, 6, 212. [CrossRef]

44. Sun, Q.; Wu, Z.; Tan, J. The relationship between land surface temperature and land use/land cover in Guangzhou, China. Environ. Earth Sci. 2012, 65, 1687-1694. [CrossRef]

45. Min, M.; Zhao, H.; Miao, C. Spatio-temporal evolution analysis of the urban heat island: A case study of Zhengzhou City, China. Sustainability 2018, 10, 1992. [CrossRef]

46. Galagoda, R.U.; Jayasinghe, G.Y.; Halwatura, R.U.; Rupasinghe, H.T. The impact of urban green infrastructure as a sustainable approach towards tropical micro-climatic changes and human thermal comfort. Urban For. Urban Green. 2018, 34, 1-9. [CrossRef]

(C) 2018 by the authors. Licensee MDPI, Basel, Switzerland. This article is an open access article distributed under the terms and conditions of the Creative Commons Attribution (CC BY) license (http://creativecommons.org/licenses/by/4.0/). 